Cahiers $d u$ MONDE RUSSE

\section{Cahiers du monde russe}

Russie - Empire russe - Union soviétique et États indépendants

45/3-4 | 2004

Varia

\title{
Thomas Sanders, Ernest Tucker, Gary Hamburg, eds., The Russian-Muslim confrontation in the Caucasus
}

\section{MOSHE GAMMER}

\section{(2) OpenEdition}

12 Journals

\section{Electronic version}

URL: https://journals. openedition.org/monderusse/4223

DOI: 10.4000/monderusse.4223

ISSN: $1777-5388$

\section{Publisher}

Éditions de l'EHESS

\section{Printed version}

Date of publication: 1 July 2004

Number of pages: $749-753$

ISBN: 2-7132-2009-2

ISSN: $1252-6576$

\section{Electronic reference}

MOSHE GAMMER, "Thomas Sanders, Ernest Tucker, Gary Hamburg, eds., The Russian-Muslim confrontation in the Caucasus", Cahiers du monde russe [Online], 45/3-4 | 2004, Online since 06 July 2009, connection on 03 September 2022. URL: http://journals.openedition.org/monderusse/4223; DOI: https://doi.org/10.4000/monderusse.4223

This text was automatically generated on 3 September 2022.

All rights reserved 


\title{
Thomas Sanders, Ernest Tucker, Gary Hamburg, eds., The Russian- Muslim confrontation in the Caucasus
}

\author{
MOSHE GAMMER
}

\section{REFERENCES}

Thomas SANDERS, Ernest TUCKER, Gary HAMBURG, eds., The Russian-Muslim confrontation in the Caucasus. Alternative visions of the conflict between Imam Shamil and the Russians, 1830-1859. With an extended commentary "War of the Worlds" by Gary HAMBURG. Londres-New York, Routledge Curzon, 2004, XV-264 p.

1 This is a most extraordinary book at least on two counts. First, academics in the humanities, unlike their colleagues in sciences and medicine, are usually known to be staunch individualists who are extremely shy of cooperating, not to say of sharing information and ideas, with others. This book is a rare exception, being the result of such collaboration. Second, it contains not one but two narratives - translations of sources from the two sides of a conflict - in "an experiment in listening through cacophony" (p. 1). Accordingly, the book is divided into three parts:

2 Part I (p. 7-74) is a translation by Ernest Tucker (from Arabic) and Thomas Sanders (from Russian) of parts of Muhammad Tahir al-Qarakhi's (1809-1880) Barikat al-Suyuf alDaghistaniyya fi ba'd al-Ghazawat al-Shamiliyya (The shining of Daghestani swords in certain campaigns of Shamil) - perhaps not "the only comprehensive history of the war from the insurgents' perspective" as the translators assert (p.1), but obviously the single chronicle to be published - and publicised - so far. Using Barabanov's published Arabic text $^{1}$ and (Russian) translation, ${ }^{2}$ Tucker and Sanders did a superb job in rendering a clear, 
fascinating and enjoyable English version of the book. The explanatory notes are helpful and illuminating, though some corrections and additions are needed.

Thus, by "red and white" (p. 62) Qarakhi refers to gold (not copper) and silver coins; in his 1854 raid on the Alazan valley Shamil captured two Georgian princesses (grand daughters of the last Georgian king), their children and French governess, not "some Georgian noble women and girls" (p. 59); the name of Shamil's most beloved wife, Shuanet, is rendered in Arabic Shu'awana (not Shawana, p. 69); Indiri and Targhu were both Ghumuq (Kumyk, not Chechen) villages, though the former had a sizable Chechen population (n. 35); chalandar derives from the Persian kalandar, meaning military man (n. 70); and Zandiqi is the Chechen village of Zandaq (p. 48, n. 78).

More essentially, the interpretation that by calling the tsar padishah,Qarakhi was "alluding to the pre-Islamic imperial Persian monarchs often regarded illegitimate by devout Muslims" (n. 9) seems a bit too far-fetched. Unlike the purely Persian pre-Islamic shahinshah, padishah was the standard term for Emperor in the world of Islam. That Qarakhi himself did not hesitate to call the Ottoman ruler "padishah of Islam" (padishah- $i$ islam, p.67), proves this point. Qarakhi, like other Muslim sources, called the tsar padishah simply because the Russian ruler carried the title Emperor.

Also, when Qarakhi recounts that General Klugenau tried in his 1837 meeting with Shamil to persuade the imam to meet "Nikolai the Russian", he meant tsar Nicholas I (then on an inspection tour of the Caucasus), not either of the brothers Nikolaÿ, who were then obviously too junior (p. 37-38 and n. 68). ${ }^{3}$ Finally, it would have been useful for the reader to learn that the battle of Shamkhal Birdi (p. 50-51) was the final episode in Vorontsov's disastrous campaign of 1845 . The Russian force reached that place "resembling a mare critically wounded by wolves" and was saved from complete destruction only by the timely arrival of Freitag, one of the most brilliant Russian generals in the Caucasus. ${ }^{4}$

Part II (p. 75-167) is a new translation of Tolstoi's Hadji Murat by Thomas Sanders and Gary Hamburg. In it the translators aimed at "convey[ing] to the readers the poetic compression and calculated strangeness of Tolstoi's Russian" and at "encod[ing] in American English [...] the class specific rhythms and idioms of Tolstoian discourse." Obviously, the previous two translations fall short of this aim: Louise and Aylmer Maude's version ${ }^{5}$ is "archaic", while the " 1977 redaction by Paul Foote" ${ }^{6}$ is "chatty" (p. 2). While the merits of each translation are a matter for professional literary critics, in the layman's opinion of this reviewer Sanders and Hamburg have achieved their goal. A comparison of the translations of a soldiers' conversation at the end of chapter 5 will clearly demonstrate it.

The present translation renders it in the following manner (p. 97):

"How many good falk that damned mountaineer has killed! Now they'll probably give him a medal," said one.

"Yeah, probably. He was Shamil's right-hand man. Now all of a sudden..."

"But he's a helluva fighter. What they call a 'dzhigit'."

"But the red-haired one. That red-haired one's an animal, he'd cut you to pieces."

"A real bastard! Has to be."

The Maudes' translation runs as follows (p. 400):

"What a lot of men that damned fellow has destroyed! And now see what a fuss they will make of him!"

"Naturally. He was Shamil's right hand, and now - no fear!"

"Still there's no denying it! He's a fine fellow - a regular dzhigit!" 
"And the red one! He squints at you like a beast!"

"Ugh! He must be a hound!"

The American English of Sanders and Hamburg stands out when compared with a 1965 translation ${ }^{7}$ using British vernacular (p. 46):

"How many men has he killed, the devil - and, look you, they're going to treat him like a lord."”

“"Snatchul, seein' as 'e was Shammul's top commander. Just watch 'im now."

"Ave it your own way, but 'e's an 'ero an' a gentleman."

"Look at the read-haired one - squint-eyed devil."”

"Must be a swine."

Part III (p. 171-249) is a substantial commentary "on the two texts in their historical context" by Gary Hamburg, who incorporated in it parts written by his colleagues. Of its thirteen chapters the first six (p. 171-199) are devoted to the historical background of the two translated texts, mainly the war in the Caucasus, the following two chapters (p. 199-211) - to Qarakhi and the Shining of Daghestani swords..., and the remaining five chapters (p. 211-238) - to Tolstoi and Khadzhi Murat.

Obviously the strongest part in both quality and length is the third one, where the author is clearly in his element. The part dealing with Qarakhi and his book is fairly comprehensive, despite the fact that more details could have been found of Qarakhi's biography. ${ }^{8}$ Another information missing (p. 211) is details of the published "preBarabanov" Russian ${ }^{9}$ and Ottoman ${ }^{10}$ translations, which are not mentioned at all even though the existence of "several Ottoman and Modern Turkish translations" has been mentioned earlier (p. 8 and n. 3).

2 One could also argue with some of the interpretations as to the purpose of episodes in the book. For example, the fact that shamil promised his son, who had not eaten for three days, that "food and water would be found at the summit of a nearby mountain" and, indeed, "a stray ally provided bread, cheese, and drink" in "that unlikely venue" does not necessarily intend to demonstrate Shamil's "control over time, natural objects and human matters" (p. 206); rather it aims at showing the imam's powers of clairvoyance.

The historical part is the most problematic. The author rightly rejects the arguments of both Russian present day historians, who continue the typically colonialist line of Soviet historiography (Russian rule "was positive not only for the Russian ruling elite, but for the entire Russian state and the peoples within it") and Western revisionists, "who invite us to shift our attention to the 'constructive' aspects of Russian colonization." Such an invitation, worns the author, "may imply that understanding the dynamics of 'frontier exchanges' and the creation of 'new social identities' on the 'mixed ground of ethnic frontiers' should take precedence in our minds over the military and cultural destruction that constituted the central acts in the Caucasus in the middle of the nineteenth century" (p. 187).

On the other hand, the early background (p.171-173) is extremely imprecise. In particular, the leap from the tenth to the fifteenth century in the description of Russia's relations with Islam leaves untouched the crucial experience of the "Tatar yoke" - the conquest and rule of Russia by the Mongols, who within a generation of establishing the "Golden Horde" converted to Islam. In addition, the description of Muscovite policy towards its Muslims is wanting. Contrary to the account in this part, Catherine II was actually the first ruler to stop the persecution and the attempts to convert Muslims by 
force and granted them rights. Also, the wording of the parts dealing with Islam and Sufism in the Caucasus leave the feeling that those subjects have not been fully understood.

Many minor and major errors, not all of them typos, lead the reader to the impression that this part was written in haste and that too tight deadlines did not allow for proper proofreading and corrections. Thus, to mention only a few, Akhulgo was stormed by the Russians in 1839 (not 1838; p. 183); Muhammad Amin was sent to the Circassians in 1848 (not 1853; p. 196); 'Abd al-Qadir surrendered to the French in 1847 (not 1846; n. 83); the zenith of Shamil's imamate was in the 1840s (not 1830s; p. 189); Berzhe is spelled in French either Berget or Bergé, but in no way Berguet (p. 210); and his 12-volume edition is of archival (not archeological) papers (p. 227-228). Paskiewicz was given officially the title "Erivanskii" by the Emperor, (not by "friends"; p. 174); and he succeeded Yermolov, so they never fought together (loc. cit.).

The imams were temporal, not spiritual leaders (p. 188); Shamil ordered to level the house of Sa'id al-Harakani in 1834 (not of Jamal al-Din in 1830; p. 190); Hadji Murad never became "a murshid in his own right" (p. 191). In fact he was never a member of any Sufi brotherhood; the "Turkish Sultan" kissed Shamil's hand in Istanbul on the imam's way to Mecca (not "when he visited Mecca"; p. 208); contrary to Qarakhi's version accepted without question that Shamil refused categorically his son, Jamal al-Din's urging to negotiate peace with the Russians (p. 201), the imam used his son as a channel for such negotiations; ${ }^{11}$ and, finally, however flattered, this reviewer cannot accept copyright for the term "demographic warfare" (p. 185), coined originally by Pinson. ${ }^{12}$

17 All these errors (hopefully to be corrected in the second edition) notwithstanding, this book will appeal to various audiences. The translators and editors marked the al-Qarakhi chronicle as intended for "those interested in the Caucasus itself, in Arabic literary culture, in Islam, and the Middle East"; Hadzhi Murat - for "Russophiles and Tolstoi enthusiasts"; and the commentary - for "specialists in the fields listed above." This part of the book, they state, contains "nothing new on the mountain war from conventional political or military perspectives," but "provides new insights into the al-Qarakhi chronicle, into the mountain insurgency as a defensive cultural movement, and into the relationship between Imam Shamil and Hadji Murat"; and "may lead researchers into some productive new ways of conceptualizing [Tolstoi's] so-called religious conversion and to new avenues for thinking about his late fiction." Finally, "post-modernist historians of culture," they add, "may see in our arrangement of material suggestive new techniques for representing alterity" (p.5). In fact, Russian-Muslim confrontation will interest and fascinate a wider audience by far with an extensive variety of interests, consisting of experts, scholars, students and laymen alike.

Finally, this book is of major significance both in its contents - mainly the two sources and as an example, hopefully to be followed by many others, of what cooperation between academics can result in. 


\section{NOTES}

1. Barikat al-Suyuf al-Daghistaniyya fi ba'd al-Ghazawat al-Shamiliyya, ed. A.M. Barabanov (Moscow - Leningrad: Izd. Akademii Nauk SSSR, 1946).

2. Khronika Mukhameda Takhira al-Karakhi o Dagestanskikh voinakh $v$ period Shamilia, Trans. A. M. Barabanov (Moscow - Leningrad: Izd. Akademii Nauk SSSR, 1941).

3. For the entire episode, see Moshe Gammer, "The Klugenau-Shamil negotiations of 1837 - A second look," Annual of the Society for the Study of Caucasia, 3 (1991): 3-12.

4. For the campaign, see Moshe Gammer, "Vorontsov's campaign of 1845: A reconstruction and re-interpretation," in: Moshe Gammer, ed., Political thought and political history. Studies in memory of Elie Kedourie (London: Frank Cass, 2003): 71-90. (The quotation is from p. 79.) For Freitag, see Moshe Gammer, "A forgotten hero of the Caucasian War - General Freytag," Annual of the Society for the Study of Caucasia, 4-5 (1992-1993): 33-43.

5. Leo Tolstoy, Short novels - Stories of God, sex and death. Vol. II. Selected and introduced by Ernest J. Simmons. Transl. (of Hadji Murád) Louise and Aylmer Maude (New York: The Modern Library, 1966).

6. Leo Tolstoy, Master and man, and other stories, translated with an introduction by Paul Foote, (Harmondsworth: Penguin, 1977).

7. Leo Tolstoy, Hadji Murat. A tale of the Caucasus, in a new translation by W. G. Carey (New York: McGraw-Hill, 1965).

8. For the most informative entry on al Qarakhi, which the authors were not yet able to use, see A. Shikhsaidov, "Al-Karakhi," Islam na territorii byvshei Rossiiskoi imperii. Entsyklopedicheskii slovar' (Moscow, 2003): 40-41.

9. Mukhamed Tagir, Tri Imama, trans. G. Mallachikhan (Makhachkala, 1927), reprinted as No. 16 in the Reprint Series of the Society for Central Asian Studies (London, 1989).

10. Tahirül-Mevlevi, Kafkasya Mucahidi Šeyh Šamil'in Gazavati, Istanbul (1333 [1914]).

11. For these negotiations, see Moshe Gammer, "The Nicolaÿ-Shamil negotiations, 1855-1856. A forgotten page of Caucasian history," Central Asian Survey, 11 (2), (1992): 43-70.

12. Marc Pinson, "Russian expulsion of mountaineers from the Caucasus, 1856-1866 and its historical background. Demographic warfare - An aspect of Ottoman and Russian policies, 1854-1866," Ph. D. Dissertation, Harvard University, 1970. 